Kohl: a Journal for Body and Gender Research

Vol. 5, No. 2 (Summer 2019)

\title{
Imagining Alternative Economies as Feminist Capital
}

Ghiwa Sayegh 
When we attempted to envision how economic justice would discursively manifest, we thought of global systems, empires, corporations, capitalist markets, and uncontainable machineries of control and power. Instead, this issue is a going back to the roots. Our contributors have looked inwardly to assemble what is meaningful to their own economies of bodies, labour, and care. Although not in direct conversation with each other yet, they collectively dreamed of economies that escape the grip of sedimented structures.

It is this collective process that we want to see materialize, for it is through critical engagement that we would be able to push for a political vision. The conference on Alternative Economies Kohl is organizing on June 21 and 22, 2019, stems from this very notion. We hope to first lay grounds by revisiting the theory and praxis of alternative economies, discussing neoliberal policies, and talking movements and access to resources. We would then move to probing the intersections - a word that is vastly misused today, used interchangeably with diverse "interests" - of labour, migration, medical patriarchy, land, and feminist organizing. Structurally, we did not have the resources to organize such a conference. Yet, we managed to squeeze budgets, time, affect, and labour to make it happen, at Mansion, an abandoned building in the heart of Beirut turned collective space. Every day, in our praxis, we attempt to embrace the messiness of processes that ultimately make up what I am calling our feminist capital.

What do the alternative economies of organizing look like? And how do some of our imaginaries manifest themselves? The manifesto of the Dammeh Cooperative maps its members' hopes for feminist economies and intersectional justice. The coop is a model of self-sustainable feminist economic practices that is reliant on its own resources. It is not dissimilar to Nubian jam'iyya, documented by Menna Agha in "The Non-Work of The Unimportant: The Shadow Economy of Nubian Women in Displacement Villages." Considered the "poor people's bank," they are in fact an alternative model to state-sanctioned resources and economic capital. Agha's self-ethnographic work maps the shadow economy of Nubian women, literally and narratively and asks the question of what constitutes "work" in the economic systems we consider to be the norm.

Throughout the issue, patriarchy and capitalism are theorized as the pillars that sustain the status quo. With such a meta-structure, what are formal economies, and whose work is considered more valuable? In "The Blindness of Political Economy: How Austerity Affects Women," Viviane Akiki insists that economic justice for women will not be possible under austerity and the failures of the welfare state. Women, she contends, juggle between poor working conditions and unpaid work in the home. But under the formal economy, care work in the domestic sphere, even when waged, is undervalued. In countries like Lebanon, migrant domestic workers are given no choice but to operate under the "legal" Kafala system, as Yasmine Kherfi explains in "Female Hysteria, Invisibilized Labour, and the Kafala System." Kherfi links the labour performed by women in neoliberal economic systems to the medical history of pathologizing women and their resistance. To this day, migrant domestic workers' rage and dissent are attributed to mental health issues and "hysteria" by a system that refuses to hold itself accountable.

With medical patriarchy, the medical industry institutionalized healing practices, tearing them away from their roots in community care. Seeking healthcare became an extractive industry geared towards maximizing profit at the expense of living-dying bodies. In "Medical Patriarchy: The Case of Legal Midwives in Lebanon," Hiba 
Abbani's ethnographic documentation digs into the histories of midwives and the advent of specialization. Prevented from practicing due to historical erasure, targeted violence, and isolation, dayas are either sidelined or demoted to auxiliaries in medical systems that look down upon their knowledge. Sophie Chamas' "The Sterility of Evil" is a moving tribute to her grandmother; she exposes the labor extracted from dying bodies, exploited by the medical industrial complex. Chamas' piece is also dedicated to her own mother, whose guilt, care, and labour are taken for granted and used against her under patriarchy and capitalism.

Whether in our feminist and queer activisms or in our conversations around alternative economies, a theorizing of class is lacking, as Nof Nasser-Eddin points out in "Reflections on Theorising Class in ArabicSpeaking Countries." Based on filed research, Nasser-Eddin conceptualizes of queerness as a differential class of its own within the domestic sphere of the family structure. However, and despite people with nonnormative sexualities being "punished" for their queerness, they are still expected to conform to normative standards and behaviors in public spheres. Saada Allaw touches upon the conversation on class in her "Interlude from Another Life." While refusing to create a sense of exceptionalism to rural settings that would reproduce the trope of rurality as "backwards," Allaw still unapologetically recounts the stories of violence she witnessed around her growing up. These experiences shaped her understanding of the conditions necessary to women's liberation in contexts that are not urban or middle to upper class - namely, patriarchal "benevolence." As for Chourouq Nasri's short story, "A Bus Ride to Ouad Nachef" would link spatial discrimination with class. Gendered violence in public transportation, another manifestation of patriarchy and capitalism, is a clear, albeit indirect, attempt at keeping public spaces and services exclusive to the use of cis-gendered men.

The forces of patriarchy and capitalism combined accumulate resources and wealth that are out of reach for alternatives to the mainstream. However, for Farah Baba, this does not mean that we should stop conceptualizing of these intersectional attempts at challenging the current status quo. "On the Depoliticization of the Economy and Activism: Notes from a feminist fresh graduate on alienation and cooptation" exposes the cooptation and subsequent depoliticization of movements by bigger NGOs, even when these consider themselves to be progressive. Baba expresses her outrage at the alienation and silencing of feminists, activists, and students who refuse to follow the prescribed route of NGOization into mainstreaming. The value of objects and invisible labor that is lost under neoliberal systems can be reclaimed through rematerialization and art, according to Azza Zein in "Rematerialization, Art, and Affective Economies." Joining her own migratory trajectory, Zein finds renewed value in the objects of her childhood memories, such as the devalued Lebanese Lira, an economic principle she applies in her artistic processes. Adopting alternative economies as a praxis requires emotional labor, as the exchange of Nadine El-Nabli and Amira Elwakil, "Neoliberal Consciousness and the Emotional Labor of Coping: A Conversation Between Friends," demonstrates. Making the links to paid work, mental health, neoliberalism, and survival, the co-discussants collectively reflect on emotional labor, which permeates as a labor of care that they practice together and with each other. Ultimately, El-Nabli and Elwakil remind us that the labor we choose to invest in each other and in our communities are perhaps our wealthiest economy - a capital that has the potential to challenge the confines of a neoliberal order. 